\title{
Exploration on the Scientific Connotation of Medical College Students' Innovation and Enterprise Ability
}

\author{
LYU Dan, LYU Jie, CHENG Hai-ping, SHAN Chun-yu, \\ School of Medical Instruments, \\ Shanghai University of Medicine \& Health Sciences, Shanghai 201318, China \\ Email: 1vd@sumhs.edu.cn
}

\begin{abstract}
On the basis of in-depth understanding of the innovation and enterprise education theory at home and abroad, this paper took "the innovation and enterprise subject of medical college students" as research object and tried to scientifically determine the basic elements of medical students' innovation and enterprise ability. Then, the effective path was actively explored to build a health science and technology innovation and enterprise system based on taking talents as the core, market as the orientation and deep integration of industry, education and research.
\end{abstract}

Keywords-Medical education; Innovation and enterprise; Cultivation mode

\section{INTRODUCTION}

"Enterprise skills and spirit must be set as the basic goal of higher education in institutions of higher education" (Declaration of the World Conference on Higher Education). In addition to traditional academic education and vocational education, current college students should also have the third pass of innovation and enterprise education. The concept of enterprise education embodies the shift of the talents training goal in institutions of higher education, emphasizes on cultivating students' competitive and professional ability, and calls for higher education to face the opportunities and challenges brought by the rapid development in the information age and knowledge economy society. The new value of higher education reform and development tends to be future-oriented, focusing on cultivating students' awareness of enterprise spirit and enterprise ability.

This paper took "the innovation and enterprise subject of medical college students" as the research object, and it is a special group, in which noble medical ethics and the aim to heal the wounded and rescue the dying are significant. Since the current understanding of the concept of innovation and enterprise education is still not clear, based on the connotation of the medical students' innovation and enterprise ability as the breakthrough point, this paper explored the effective practice of cultivating the ability of medical students' innovation and enterprise ability platform.

\section{CONNOTATION ORIENTATION OF MEDICAL COLLEGE STUDENTS' INNOVATION ABILITY}

\section{A. Concept of innovation ability}

The concept of "innovation theory" was first put forward in the book of economic development theory by Joseph Alois Schumpeter, the famous Austria political economist in 1912. Innovation was defined as the new combination of productive factors by entrepreneur, and innovation is summarized as five types of product innovation, production method innovation, market innovation, raw material innovation and organizational innovation [1]. The concept of innovation ability was first proposed in 1961, and it was originally used to describe the ability of an organization to successfully adopt or implement new ideas, processes, and products.

Innovation ability, in general, is referred to creatively putting forward a new invention on the basis of predecessors' discoveries or inventions, and it is also referred to the skills of problem finding, analyzing, doubting, critical reasoning and solving. Innovation ability is the subject's capacity of continuously providing new ideas, new theory, and new invention rich in social, ecological, and economic value in the field of science, art, techniques and various practical activities [2-4].

\section{B. Scientific connotation of innovative ability of medical college students}

With the vigorous development of the massive health industry, the whole society has put forward new requirements on medical education. The requirements for medical students professional clinical technical knowledge are constantly improved, on the other hand, the medical environment also clearly proposes that high-quality medical practitioners must have good teamwork spirit, systematic analysis and practical ability to adapt to the innovative needs of modern clinical technology, clinical products and clinical services.

On the basis of in-depth interpretation of General Secretary Xi Jin-ping's Healthy China 2030 program strategy, the paper started mainly from the hierarchy structure of the innovation ability, at the same time, fully considered the traditional medical students' training mode and social factors such as the special requirements for the medical workers, and 
further defined the scientific connotation of medical students' innovation ability. Medical college students' innovation ability is defined as the comprehensive capability of the medical students serving in clinical professional and post to put forward new ideas for clinical products or services aiming to solve new problems with a strong sense of innovation and clear creative goals.

\section{SCIENTIFIC CONNOTATION OF ENTERPRISE ABILITY OF MEDICAL COLLEGE STUDENTS}

The former United States Commerce Secretary Peter G. Peterson defined entrepreneurship as a discovery and opportunity capture resulting in creating innovative products and services or to achieve potential value of the whole process. Association of global entrepreneurship based on personal experience as early as 1971. The former Global Entrepreneurship Federation's President Charles H. Matthews defined entrepreneurship as to create new business models or the process of new high-tech products[5]. In 1998 the famous American management scientist Morris M.H. summarized 77 enterprise definitions collected from the core journal articles and major textbooks in Europe and the United States, and then revealed the five connotations of enterprise, which included creating new businesses, creating new organizations, combining innovation resources, capturing opportunities, risk taking and value creating[6].

The definition of enterprise in this paper focused on the process of medical students' entrepreneurs creating new jobs or starting a new career in clinical medical work to create innovation and make greater progress in clinical market, by making full use of various main resources (mainly including knowledge, technology, thinking, funding, and opportunities, etc.).

"Creation" is a dynamic process, which requires the entrepreneur to make persistent efforts, while "enterprise" is a result, which means to the final results achieved by the entrepreneurs' efforts. The whole category of enterprise ability includes entrepreneurial awareness, entrepreneurial thinking, and entrepreneurial skills, which are involved in the entrepreneurial process through the final results of the entrepreneur's efforts.

Considering the glorious mission of medical students, the enterprise activity not only involves the relationship between human and nature, more involved in the relationship of the people and society, the content is richer and broader. The complete definition of medical students' enterprise ability should includes entrepreneurial awareness (gumption and sensitivity of clinical market opportunities, etc.), entrepreneurial qualification (decision-making, strength endurance, experience and professional ethics, etc.) and entrepreneurial skills (knowledge, technology, attitudes and skills to deal with the public relations, as well as organizing ability, etc.).

\section{COMPREHENSIVE UNDERSTANDING OF INNOVATION AND ENTERPRISE ABILITY OF MEDICAL COLLEGE STUDENTS}

Joseph Alois Schumpeter, the famous Austrian political economist, once pointed out that entrepreneurship is the process to achieve innovation, and innovation is the essence and means of entrepreneurship. The decision of the CPC central committee and the state council to deepen education reform and comprehensively promote education was first put forward in 1999. Higher education should attach importance to cultivate the innovative ability, practice ability and entrepreneurial spirit of college students, aiming to improve the humanities and science literacy of college students. In the process of defining the concept of entrepreneurship, this paper especially emphasized the fundamental role from innovation ability in promoting the development of enterprise ability, as a result, innovation and enterprise ability is combined as a whole concept for consideration in this paper.

In 1998 UNESCO World Conference on higher education formed the universal declaration of higher education and pointed out that higher education should mainly develop entrepreneurial and initiative skills, thus graduates would become no longer just job seekers, but they would become the creators of work. That is a new concept of higher education, and it is the fundamental change of higher education cultivation mode. So what elements constitute medical students' innovation and enterprise ability? This paper finally determined that the innovation and enterprise ability of medical students is formed by the organic integration of six basic elements of innovation consciousness, planning ability, organizing ability, management ability, coordination communication ability and learning ability.

The first basic element is innovation consciousness. Enterprise teams carefully analyze the disadvantages of a certain service or product in clinical medical market, and purposefully put forward ingenious ideas with the combination of clinical medical and engineering knowledge, then work out feasible implementing scheme under thorough reasoning. It is excellent practice of innovation ability. Innovation is the foundation of entrepreneurship, entrepreneurship is a form of innovation. Carve out on the basis of innovation, and make innovative during entrepreneurship process. Innovation consciousness provides possibility and necessary preparations for entrepreneurial.

The second basic element is the planning ability. It refers to that after analyzing the entrepreneurial environment objectively and impartially, enterprise teams define the teams' future development direction, goals and strategies, and formulates the practical enterprise plan, then makes reasonable planning for the future development and rapid growth of the teams.

The third basic element is organizing ability. Enterprise teams always gain clear enterprise goals, and adopt effective methods to scientifically and efficiently organize various elements and links of enterprise activity, joining them from time and space, building efficient enterprise teams with super cohesive force. 
The fourth basic element is management ability. Management ability is the ability of the manager of the enterprise team to coordinate and guide the team members in a timely manner, ensuring the normal operation of enterprise activities, and ensuring the realization of the development goals of the enterprise team as scheduled.

The fifth basic element is coordination communication ability. Coordination ability is the ability of the enterprise team to solve all aspects of contradictions, so that all team members can closely cooperate with unified actions to achieve the development goals of enterprise team.

The final basic element is learning ability. It is not only refers to learning book knowledge from teachers, but also points to sustainable learning ability formed through information collection, processing and utilization of the whole process. Besides sensory, memory, and analysis, it is also important to master certain learning methods and strategies.

\section{CONCLUSION}

Innovation and enterprise ability cultivation is not the simple sum of innovation and enterprise education, in fact it is a foregoing step upon innovative education and enterprise education both in concept and content. Innovation and enterprise education is not the intersection of the two concepts, but a new complete concept, which guides higher education to constantly update education concept, education content and teaching methods.

Although the current innovation and enterprise education is flourishing in China, but there are a lot of development bottlenecks. For example, the subject status of innovation and enterprise education is marginalized. And the degree of course systemization is needed to ascend. There are quite fewer innovation and enterprise courses in colleges. Practical teaching link is weak, especially in medical students' innovative and enterprise field [7].

The development of innovation and enterprise ability of medical college students fully embodies the characteristics of education quality engineering and multi-orientation of medical college. Its essence is an organic combination of innovation consciousness, entrepreneurship quality and students' vocational skills. Persistently helping students to recognize themselves and their lives, form a self-occupational image of sustained development and dynamic rise, foster a spirit of innovation and a firm sense of enterprise, as well as promoting students' innovative and enterprise behavior, are valuable experiences from SUMHS. Aimed to provide high standards for the development of social and medical health services, application-oriented medical talents strive to promote the great strategy of Healthy China.

\section{REFERENCES}

[1] Freeman C, Soete L. The Economics of Industrial Innovation[M]. Cambridge :The MIT Press, 1997:217-219.

[2] Guilford J P. Traits of Creativity[M]. New York: Harper\&Publisher, 1959:142-161.

[3] Chen Jian-cheng, Li Yong, Zhang Jing, et al., Studies on the characteristics of educating creative talents in foreign research universities and the implications for Chinese top universities[J], ScienceTechnology and Management, 2009, 11(1):130-133. (In Chinese)

[4] Gao Mei-cai, Chen Bo, Three dimensional Research on College Students' innovative ability[J], Jiangsu Higher Education, 2003, (1):2628. (In Chinese)

[5] Shi Guo-liang, Innovation and enterprise education for college students [M], YANJIU Press, 2010:34-35. (In Chinese)

[6] Stevenson H H, Roberts M J, Grousbeck H I, New Business Ventures and the Enterpreneur(5th ed)[M],TSINGHUA University Press , 2002:9-11.

[7] Liu Wei, Reflections on the construction of talents training system for innovation and entrepreneurship education in Colleges and Universities [J], Education Science, 2011,27(5):64-67. (In Chinese) 